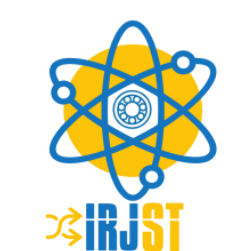

Available online at https://www.irjst.com/

International Research Journal of Science and Technology

ISSN: $2707-3955$

DOI: https://doi.org/10.46378/irjst.2020.010403

\title{
Study of Toxic and Non-Toxic Metals in the Blood of Smokers and Non-Smokers by Atomic Absorption Spectroscopy.
}

\author{
Aleeza Javeed $^{1 *}$, Iqra Azam ${ }^{1}$ and Humayun Ajaz ${ }^{1}$ \\ ${ }^{1}$ Department of Chemistry, University of Engineering and Technology, Lahore-54000, Pakistan.
}

\begin{tabular}{llll}
\multicolumn{2}{ll}{ Paper Status } & & \\
Received : & Aug 2020 \\
Accepted : & Sep 2020 \\
Published : & Sep 2020
\end{tabular}

Key Words

Cigarette Smoking

Non-Toxic Metals

Tobacco Toxic Metals

Surbex $Z$.

\begin{abstract}
Cigarette smoking is considered as addictive and destructive behaviour. It creates health problems and variation in different parameters of blood. Cigarette smoking also causes environmental pollution by releasing toxic air pollutants into the atmosphere. Analysis of Lead (Pb), Cadmium (Cd) and Iron (Fe) in blood of smokers and non-smokers was done by Atomic Absorption Spectroscopy and there was also comparison of effect of cigarette smoking on haemoglobin $(\mathrm{Hb})$ between smokers and non-smokers before and after medication. Samples of smokers and non-smokers were collected from different areas of Lahore. After experimentation, statistics applied for conclusion. Samples of smokers and non-smokers were collected to compare the effect of smoking on $\mathrm{Hb}$ before and after medication. Smokers and non-smokers were medicated by medicine Surbex $\mathrm{Z}$ for one week. The $\mathrm{Hb}$ level of smokers and nonsmokers was noted before and after medication. Time duration has been taken into account for effective medication.
\end{abstract}

\footnotetext{
Copyright ( ) 2020: Aleeza Javeed, Iqra Azam and Humayun Ajaz.This is an open-access distribution, and reproduction in any medium provided Access article distributed under the Creative Commons Attribution License the original work is properly cited License, which permits unrestricted use.

Citation: Aleeza Javeed, Iqra Azam and Humayun Ajaz. "Study of Toxic and Non-Toxic Metals in the Blood of Smokers and Non-Smokers by Atomic Absorption Spectroscopy". International Research Journal of Science and Technology, 1 (4), 286-291, 2020.
}

\section{Introduction}

Pakistan is an agricultural country. Only $0.27 \%$ of the total land is used for cultivation of tobacco in Pakistan. The annual production of tobacco is $70-75$ million $\mathrm{kg}$, whereas the domestic requirement is $40-50$ million $\mathrm{kg}$; the rest $30-35$ million $\mathrm{kg}$ is exported. In most of the countries of the world the consumption of cigarettes is falling while in Pakistan, the production and consumption of this nonessential poisonous item is increasing at an alarming rate. It is surprising that the world is fighting against smoking, an increasing number of Pakistani peoples setting new records by manufacturing an additional five billion cigarettes each year. The smoking rate among males is more than $50 \%$, whereas it is $10 \%$ in females in Pakistan [1].

Tobacco is herbaceous plant and it is commercially cultivated. Tobacco processed into cigarettes. The scientific name of tobacco is Nicotiana tobaccum L.

\footnotetext{
* Corresponding Author: Aleeza Javeed

Department of Chemistry, University of Engineering and $b$

Technology, Lahore-54000, Pakistan

Email: aleezajavaid778@gmail.com
}

Nicotine alkaloid exist in leaves of tobacco which considered as an important component that induces cigarette addiction. Leaves of raw tobacco and smoke of cigarette contain 250 well-known destructive metal toxicants and phytochemicals, 69 of them cause cancer [2].

Smoking is uniquely human habit indulge in almost all over the world in different forms [3]. Smoking is a process in which tobacco is burnt and smoke is inhaled by different ways i.e., Cigarette, Cigar, Biri and Pipe [4]. Smoking has both acute and chronic effect on haematological parameters [5]. There are more than 4000 chemicals found in cigarette smoke [6]. Cigarette smoking considered as addictive and destructive behavior. Serious health problems were caused by smoking of cigarette. Globally, preventable cause of death was also cigarette smoking, there are severe effect of smoking on health [7]. Habitual smoking has an adverse health effects. Numbers of xenobiotic, including heavy metals such as $\mathrm{Cd}$ and $\mathrm{Pb}$ are 
produced by smoking [8]. People mostly captivated to nicotine practiced smoking [9].

Studies have shown that, each year about 3000 nonsmoking adults' die of lung cancer as a result of breathing the second-hand smoke from other's cigarette [10]. Rottman in 1898 first claimed that tobacco use might reason of lung cancer. Lung, larynx, pharynx, esophagus, oral cavity, pancreas, urinary bladder and renal pelvic cancers are strongly related to tobacco use [11]. Due to cigarette smoking, there is an estimation of 443,000 deaths in the United States (US) per year. Cigarette smoke leads towards fatal diseases Cigarette smoke contains variety of toxicants including polycyclic aromatic hydrocarbons, volatile organic compound, nitrosamines and numerous toxic heavy metals. There is International Agency for Research on cancer. This agency designated some metals as carcinogenic to humans. That metals that are carcinogenic to humans are $\mathrm{Cd}, \mathrm{As}, \mathrm{Cr}(\mathrm{VI})$ and $\mathrm{Ni}$ compounds [12]. A single cigarette contains 1.0-4.5 $\mu \mathrm{g} \mathrm{Cd}$. An increase in blood pressure; prevalence of hypertension, and cardiovascular disease resulted from exposure to cadmium. An exogenous source of metals contamination in human body is smoking [13].

The most significant reason of morbidity and mortality in the world is the use of tobacco products. Tobacco plant is well recognized for its capacity to concentrate toxic elements (TEs) from its mounting environment. Different cigarette brands have different smoke and thus different level of toxic elements. This level depends upon where the tobacco was grown. There is advancement in cigarette designs over the last decades. This advancement is with the incorporation of new tobacco processes, papers, filters, and several ingredients (flavours and casing materials) $[14,15]$.

In soil, there is variety of heavy metal species. From soil heavy metal species gathered by tobacco plants and then transferred to leaves [16]. Tobacco plants very easily take up $\mathrm{Cd}$ and $\mathrm{Pb}$ from soil and concentrate them in leaves [17].

Cigarette smoke is one of the potential sources of toxic iron. When excess of iron accumulates in the body, it leads towards different diseases that also include cancer. Iron produces free radicals, as in human body it is present in ferrous state. In cruel state, iron with oxidizing reagents (hydrogen dioxide) reacts and produce free radicals. The radicals are formed and natural antioxidants are used to control and to remove these radicals under normal conditions. These radicals got accumulated when the iron concentration systematically increases. In lungs of almost all cigarette smokers, in the form of extracellular ferritinbound iron, there is more concentration of iron. An important task is to estimate reliably as a result of smoking, the amount of iron absorbed and transferred [18]. Mostly, the common methods used for smoking are industrially manufactured cigarettes and hand rolled from loose tobacco and rolling paper.

Pipes, Cigar, Hookahs, Vaporizers and Bongs are other smoking riggings. More than four thousands chemical compounds are produced by burning of tobacco and paper. The haemoglobin $(\mathrm{Hb})$ concentration in blood increased due to smoking. In cigarette smoke, carbon monoxide is present. Carbon monoxide binds to $\mathrm{Hb}$ to form carboxyhaemoglobin. Carboxyhaemoglobin is an inactive form of haemoglobin having no oxygen carrying capacity. Haemoglobin $(\mathrm{Hb})$ level of cigarette smokers is observed higher than the persons who do not smoke [19, 20].Scientific literature provides evidence that chemical compounds and emitted gasses in tobacco smoke have harmful health effects. Now days, International Agency for Research on Cancer (IARC) classified cadmium (Cd) as well as nickel (Ni) and arsenic (As) as cancer causing elements to humanity among 87 mainly organic carcinogens. Heavy metals that inhaled through smoking have long biological life. Great contributor on total level of concentration of cadmium $(\mathrm{Cd})$ and lead $(\mathrm{Pb})$ in blood is tobacco. Usually, great amount of $\mathrm{Cd}$ absorbed through human body by smokers.

There is inhalation of $1-2 \mu \mathrm{g}$ of $\mathrm{Cd}$ by smoking of one cigarette. $\mathrm{Cd}$ caused oxidative DNA damage by several oxygen species. Increasing lipid peroxidation, induction of oxidative stress and inhibition of enzymes responsible from DNA repair also caused by $(\mathrm{Cd})$. Moreover, $\mathrm{Cd}$ is also responsible for testicular damage, hypertension, atherosclerosis, osteoporosis and cancer. Due to $\mathrm{Pb}$ concentration in blood there are unwanted effects such as anemia, rise in blood pressure, kidney damage, and disruption of nervous system, brain damage and declined fertility of men through sperm damage [21, 22]. However the aims of research work are analysis of toxicity of toxic metals in cigarette smoke, Comparative analysis of toxic metal concentration present in both smokers and nonsmoker's blood, analysis of nutritional trace metal and the comparison when nutritional supplements are provided and comparison between smokers and nonsmokers of cigarette smoking sound effects on hemoglobin $(\mathrm{Hb})$ level.

\section{Experimental Work}

Blood samples of smokers (S) and non-smokers (NS) were collected from different areas of Lahore. For sampling, to some volunteer's smokers as well as nonsmokers, tablet of Surbex $\mathrm{z}$ was given for one week to compare the effect of medicine on $\mathrm{Hb}$ before and after medication. Samples of smokers and non-smokers were collected before and after medication marked as medicated smokers (MS) and medicated non-smokers (MNS). After that ethylene diamine tetra acetic acid (EDTA) vials was used for storage of sample. 
Table 1. Metal Concentration in $(\mu \mathrm{g} / \mathrm{g})$ in Blood of Smokers in Urban Areas

\begin{tabular}{lllll}
\hline \multirow{2}{*}{ Area } & No of Smoker & $\begin{array}{l}\mathrm{Cd} \\
(\mathrm{ug} / \mathrm{g})\end{array}$ & $\begin{array}{l}\mathrm{Pb} \\
(\mathrm{ug} / \mathrm{g})\end{array}$ & $\begin{array}{l}\mathrm{Fe} \\
\mathrm{ug} / \mathrm{g})\end{array}$ \\
\hline \multirow{4}{*}{ Urban Area } & 2 & $0.7 \pm 0.1$ & $20.77 \pm 0.15$ & $73.82 \pm 0.08$ \\
& 1 & $0.6 \pm 0.2$ & $27.15 \pm 0.15$ & $100.33 \pm 0.18$ \\
& 3 & $0.9 \pm 0.2$ & $20.82 \pm 0.13$ & $85.5 \pm 0.78$ \\
& 4 & $0.8 \pm 0.1$ & $28.2 \pm 0.26$ & $100.58 \pm 0.04$ \\
& 5 & $1.2 \pm 0.1$ & $38.15 \pm 0.22$ & $104.98 \pm 0.13$ \\
\hline
\end{tabular}

Table 2. Metal Concentration in $(\mu \mathrm{g} / \mathrm{g})$ in Blood of Smokers in Rural Areas

\begin{tabular}{lllll}
\hline Area & No of Smoker & $\begin{array}{l}\mathrm{Cd} \\
(\mathrm{ug} / \mathrm{g})\end{array}$ & $\begin{array}{l}\mathrm{Pb} \\
(\mathrm{ug} / \mathrm{g})\end{array}$ & $\begin{array}{l}\mathrm{Fe} \\
(\mathrm{ug} / \mathrm{g})\end{array}$ \\
\hline \multirow{3}{*}{ Rural Area } & 1 & $1.1 \pm 0.1$ & $33.15 \pm 0.06$ & $89.52 \pm 0.1$ \\
& 2 & $1.3 \pm 0.1$ & $13.9 \pm 0.2$ & $159.93 \pm 0.15$ \\
& 4 & $0.8 \pm 0.1$ & $16.93 \pm 0.26$ & $118.5 \pm 0.1$ \\
& 5 & $0.8 \pm 0.2$ & $14 \pm 0.17$ & $86.57 \pm 0.15$ \\
& $0.9 \pm 0.1$ & $12.43 \pm 0.21$ & $67.77 \pm 0.12$ \\
\hline
\end{tabular}

Table3. Metal Concentration in $(\mu \mathrm{g} / \mathrm{g})$ in Blood of Smokers in Hilly Areas

\begin{tabular}{ccccc}
\hline Area & $\begin{array}{c}\text { No of } \\
\text { Smoker }\end{array}$ & $\begin{array}{c}\mathrm{Cd} \\
(\mathrm{ug} / \mathrm{g})\end{array}$ & $\begin{array}{c}\mathrm{Pb} \\
(\mathrm{ug} / \mathrm{g})\end{array}$ & $\begin{array}{c}\mathrm{Fe} \\
(\mathrm{ug} / \mathrm{g})\end{array}$ \\
\hline \multirow{6}{*}{ Hilly Area } & 1 & $1.1 \pm 0.2$ & $17.97 \pm 0.16$ & $124.92 \pm 0.16$ \\
& 2 & $0.9 \pm 0.1$ & $17.51 \pm 0.11$ & $131.13 \pm 0.25$ \\
& 3 & $0.9 \pm 0.2$ & $17.99 \pm 0.12$ & $117.62 \pm 0.03$ \\
& 4 & $1.3 \pm 0.2$ & $38.27 \pm 0.16$ & $105.05 \pm 0.13$ \\
& 5 & $1.2 \pm 0.1$ & $18.02 \pm 0.16$ & $80.96 \pm 0.2$ \\
\hline
\end{tabular}

Table 4. Metal Concentration in $(\mu \mathrm{g} / \mathrm{g})$ in Blood of Non-Smokers in Urban Areas

\begin{tabular}{ccccc}
\hline Area & No of Non-Smoker & $\begin{array}{c}\mathrm{Cd} \\
(\mathrm{ug} / \mathrm{g})\end{array}$ & $\begin{array}{c}\mathrm{Pb} \\
(\mathrm{ug} / \mathrm{g})\end{array}$ & $\begin{array}{c}\mathrm{Fe} \\
(\mathrm{ug} / \mathrm{g})\end{array}$ \\
\hline \multirow{4}{*}{ Urban Area } & 1 & $2.1 \pm 0.1$ & $12.1 \pm 0.2$ & $62.2 \pm 0.3$ \\
& 2 & $1.7 \pm 0.1$ & $9.5 \pm 0.2$ & $46.7 \pm 0.2$ \\
& 3 & $1.9 \pm 0.2$ & $21.3 \pm 0.2$ & $59.2 \pm 0.7$ \\
& 4 & $1.5 \pm 0.1$ & $26.9 \pm 0.1$ & $76.3 \pm 0.2$ \\
\hline
\end{tabular}

Table 5. Metal Concentration in $(\mu \mathrm{g} / \mathrm{g})$ in Blood of Non-Smokers in Rural Areas

\begin{tabular}{lllll}
\hline \multirow{2}{*}{ Area } & \multirow{2}{*}{ No of Non-Smoker } & $\begin{array}{l}\mathrm{Cd} \\
(\mathrm{ug} / \mathrm{g})\end{array}$ & $\begin{array}{l}\mathrm{Pb} \\
(\mathrm{ug} / \mathrm{g})\end{array}$ & $\begin{array}{l}\mathrm{Fe} \\
(\mathrm{ug} / \mathrm{g})\end{array}$ \\
\hline \multirow{4}{*}{ Rural Area } & 1 & $2.5 \pm 0.2$ & $23.9 \pm 0.2$ & $63.6 \pm 0.2$ \\
& 2 & $1.9 \pm 0.1$ & $40.5 \pm 0.1$ & $42.1 \pm 0.2$ \\
& 3 & $2.3 \pm 0.2$ & $25 \pm 0.2$ & $50.4 \pm 0.2$ \\
& 5 & $2.8 \pm 0.2$ & $24.7 \pm 0.1$ & $47 \pm 0.3$ \\
& 5 & $2.7 \pm 0.2$ & $21.1 \pm 0.2$ & $52.3 \pm 0.2$ \\
\hline
\end{tabular}


Table 6 Metal Concentration in $(\mu \mathrm{g} / \mathrm{g})$ in Blood of Non-Smokers in Hilly Areas

\begin{tabular}{lllll}
\hline \multirow{2}{*}{ Area } & $\begin{array}{l}\text { No of } \\
\text { Non- } \\
\text { Smoker }\end{array}$ & $\begin{array}{l}\mathrm{Cd} \\
(\mathrm{ug} / \mathrm{g})\end{array}$ & $\begin{array}{l}\mathrm{Pb} \\
(\mathrm{ug} / \mathrm{g})\end{array}$ & $\begin{array}{l}\mathrm{Fe} \\
(\mathrm{ug} / \mathrm{g})\end{array}$ \\
\hline \multirow{3}{*}{ Hilly Area } & 1 & $1.9 \pm 0.2$ & $31 \pm 0.2$ & $47 \pm 0.2$ \\
& 2 & $1.9 \pm 0.1$ & $24.5 \pm 0.1$ & $40 \pm 0.2$ \\
& 3 & $1.6 \pm 0.1$ & $25 \pm 0.3$ & $66.5 \pm 0.4$ \\
& 4 & $1.8 \pm 0.1$ & $35.3 \pm 0.2$ & $52.3 \pm 0.2$ \\
& 5 & $1.5 \pm 0.1$ & $39 \pm 0.2$ & $66.3 \pm 0.2$ \\
\hline
\end{tabular}

Table 7. Comparison of Hb between Medicated Smokers (MS) and Medicated Non-Smokers (MNS) before and after Medication

\begin{tabular}{cccc}
\hline Sample & Age (Years) & $\mathrm{Hb}(\mathrm{HL})$ & $\mathrm{Hb}(\mathrm{HL})$ \\
\hline 1MS & 32 & 14.3 & 13.5 \\
$2 \mathrm{MS}$ & 40 & 12.8 & 14.0 \\
3MS & 21 & 13.4 & 14.5 \\
$4 \mathrm{MS}$ & 52 & 11.5 & 13.7 \\
$5 \mathrm{MS}$ & 40 & 10.2 & 13.2 \\
$6 \mathrm{MNS}$ & 30 & 12.6 & 13.9 \\
$7 \mathrm{MNS}$ & 18 & 13.0 & 14.8 \\
$8 \mathrm{MNS}$ & 27 & 12.1 & 12.6 \\
$9 \mathrm{MNS}$ & 27 & 10.3 & 12.1 \\
$10 \mathrm{MS}$ & 57 & 12.3 & 13.1 \\
\hline
\end{tabular}

For digestion of blood, $1 \mathrm{ml}$ blood sample from EDTA vials was put into china dish containing $7 \mathrm{ml}$ conc. $\mathrm{HNO}_{3}$, using measuring cylinder. Sample was heated on flame until dried and cooled to obtain residue of blood. Same procedure was repeated three times but first time with $7 \mathrm{ml}$ conc. $\mathrm{HNO}_{3}$, second time with $2 \mathrm{ml} \mathrm{H}_{2} \mathrm{O}_{2}$, and third time again with $2 \mathrm{ml}$ conc. $\mathrm{HNO}_{3}$. At last digested blood sample diluted up to $50 \mathrm{ml}$ using distilled water.

\section{Characterization}

Varian flame atomic absorption spectrometer model AA240 was used for metal detection followed by Beer Lambert's law. In inorganic and organic materials AAS is one of the important instrumental techniques for both quantitative and qualitative analysis of metallic and non-metallic elements. This technique is element selective and provides analytical sensitivities as the parts per million level and less (where 1 part-per million is $0.0001 \%$ ) [23]. Further data has been used for numerical analysis.

\section{Results and Discussion}

Iron dissolved more in blood of smokers than lead and cadmium. Rich quantity of $\mathrm{Cd}$ is present in cigarettes and analyzed by atomic absorption spectroscopy. In addition to that $\mathrm{Cd}$ is less dissolved in blood of smokers and more deposited in body causing different diseases. Although, excess of iron accumulates in the body leads towards different diseases including cancer. Cigarette smoke is one of the potential sources of toxic iron. In human body iron is present in ferrous state.
Iron reacts with different oxidizing reagents e.g. hydrogen dioxide and produce free radicals. Iron concentration systematically increases when radicals got accumulated [24].

$\mathrm{Pb}, \mathrm{Cd}$ and $\mathrm{Fe}$ are produced by cigarette smoking, when a person smoke tobacco cigarette these metals are accumulated in body. $\mathrm{Pb}$ is slightly higher in smokers than non-smokers. Many studies have demonstrated that cigarette smoking results in an elevation of blood lead levels [25]. More study have been reported that one cigarette contains about $0.5-2$ $\mathrm{mg}$ of cadmium and that about $10 \%$ of the cadmium content is inhaled when the cigarette is smoked. Smokers generally exhibit higher concentration of cadmium than non-smokers [26, 27]. Smokers and non-smokers are medicated by medicine Surbex $\mathrm{Z}$ for one week. The $\mathrm{Hb}$ level of smokers and non-smokers was noted before and after medication. Moreover, data was recorded and shown in table7. Surbex $\mathrm{Z}$ is product of combination of $\mathrm{B}$ vitamins to treat or prevent vitamin deficiency due to poor diet, certain illness and alcoholism [28]. It is resolved that the medicine Surbex $\mathrm{Z}$ can be used to maintain $\mathrm{Hb}$ level of smokers as well as non-smokers. Concentration of $\mathrm{Pb}, \mathrm{Cd}$ and Fe is given in tables 1-6. Fe dissolved more in blood of smokers, then $\mathrm{Pb}$ and less amount of $\mathrm{Cd}$ is dissolved.

Among various environmental pollutions in the urban area, heavy metals have the most harmful effect on public health, because they remain in the ecosystem and are not biodegradable [29]. Tobacco becomes a vital source of toxic metals [30]. The weight of the 
cigarettes ranges from 0.91 to $1.16 \mathrm{~g}$. The average weight of the cigarettes without the fitter is $0.86 \mathrm{~g}$ (range $0.77-0.96 \mathrm{~g}$ ) [31]. Local cigarettes had a mean cadmium concentration $3.12 \mu \mathrm{g} / \mathrm{g}$ with a standard deviation of $0.06 \mu \mathrm{g} / \mathrm{g}$ whereas imported brands showed a cadmium concentration average $2.47 \mu \mathrm{g} / \mathrm{g}$ with a standard deviation of $0.41 \mu \mathrm{g} / \mathrm{g}$. Pb concentration in local cigarette brands is $2.27 \pm 0.27 \mu \mathrm{g} / \mathrm{g}$ and in imported cigarette brands is $1.69 \pm 0.44 \mu \mathrm{g} / \mathrm{g}$. Therefore, higher concentration of $\mathrm{Pb}$ and $\mathrm{Cd}$ was observed in local cigarette brands as compare to imported cigarette brands [32]. Tobacco smoking is the most significant single source of $\mathrm{Cd}$ exposure in the general population. It can be estimated that a person smoking 20 cigarettes per day takes about up to $1 \mu \mathrm{g}$ of $\mathrm{Cd}$ per day [33].

Regular cigarette smoking greatly increases lung exposure to iron [34]. Haemoglobin, or ' $\mathrm{Hb}$ ', is a protein that contains iron and is found in red blood cells. It carries oxygen around the body and gives blood its red color. Hb levels vary from person to person and there are various reasons in variation of $\mathrm{Hb}$ levels. Smoking is one of the reasons in variation of $\mathrm{Hb}$ levels. Smokers show high $\mathrm{Hb}$ level than nonsmokers [35].

\section{Conclusion}

$\mathrm{Pb}, \mathrm{Cd}$ and $\mathrm{Fe}$ are produced by cigarette smoking, when a person smoke tobacco cigarette these metals are accumulated in body. It is concluded that $\mathrm{Fe}$ dissolved more in blood of smokers, then $\mathrm{Pb}$ and less amount of $\mathrm{Cd}$ is dissolved. Although $\mathrm{Cd}$ is present in excess in cigarettes but it is analysed by atomic absorption spectroscopy (AAS) that $\mathrm{Cd}$ is less dissolved in blood of smokers and more deposited in body causing different diseases. The Haemoglobin $\mathrm{Hb}$ concentration increased in blood due to smoking. In present research work, smokers and non-smokers are medicated by medicine Surbex $\mathrm{Z}$ for one week. The $\mathrm{Hb}$ level of smokers and non-smokers was noted before and after medication. Before medication the $\mathrm{Hb}$ of smokers was in the range of 10-13. Then medication was started for one week and it was observed that the $\mathrm{Hb}$ goes increased. It might be happened because of many reasons as they are not chain smokers or they are not habitual in smoking. Chain smokers and habitual smokers show high $\mathrm{Hb}$ level. In 1 sample labelled as $1 \mathrm{MS}$ the $\mathrm{Hb}$ level was observed high and after medication for 1 week, it was maintained under desire range. When Surbex $\mathrm{Z}$ is used for non-smokers, the $\mathrm{Hb}$ level goes high. It is resolved that the medicine Surbex $\mathrm{Z}$ can be used to maintain $\mathrm{Hb}$ level of smokers as well as non-smokers.

\section{Acknowledgement}

This study was supported by Inorganic Lab in the Department of Chemistry, University of Engineering and Technology, Lahore 54000, Pakistan.

\section{References}

[1]. Bukhari IH, Rasul N, Kausar S, et al. Comparative studies of $\mathrm{Ni}, \mathrm{Cd}, \mathrm{Mn}, \mathrm{Co}, \mathrm{Pb}$, $\mathrm{Cr}$ and $\mathrm{Zn}$ in hair, nail and plasma of smokers and non-smokers subjects of Sargodha zone. Int J Chem Biol Sci. 2013; 4: 28-37.

[2]. Benson NU, Anake WU, Adedapo AE, et al. Toxic metals in cigarettes and human health risk assessment associated with inhalation exposure. Environ Monit Assess. 2017; 189(12): 619.

[3]. Jeganathan J \& Chowta N. Study of effect of smoking on blood pressure in normotensive men. Int J Med Public Health. 2012; 2(4):43.

[4]. Ibrahim KM, Bukhari MH, Akhtar MS, et al. Effect of smoking on red blood cells count, hemoglobin concentration and red cell indices. Pak J Med Health Sci. 2014; 8(2): 361.

[5]. Shenwai MR \& Aundhakar NV. Effect of cigarette smoking on various hematological parameters in youngmale smokers. Indian $\mathbf{J}$ Basic Appl Med Res. 2012; 2(5): 386-92.

[6]. Asif M, Karim S, Umar Z, et al. Effect of cigarette smoking based on hematological parameters: comparison between male smokers and non-smokers. Turk J Bio Chem. 2013; 38(1):75-80.

[7]. Jamil N, Bazai ZA, Riaz $M$, et al. Comparative Analysis of Smoking Impact on Health of Smokers and Non-Smokers of Quetta City Dwellers. Environ Eco Res. 2014; 2(7): 272-278.

[8]. Galażyn-Sidorczuk M, Brzóska MM \& Moniuszko-Jakoniuk, J. Estimation of Polish cigarettes contamination with cadmium and lead, and exposure to these metals via smoking. Environ Monit Assess. 2008; 137(13):481-493.

[9]. Paracha PI, Khan T, Vriesekoop F, et al. Association between Smoking and Anthropometric Characteristics, Biochemical Markers, and Dietary Intake of Pakistani Male Adult Population. Adv Food Technol Nutr Sci Open J. 2015; 1(4): 88-96.

[10]. Ziarati P, Mousavi Z \& Pashapour S. Analysis of Heavy Metals in Cigarette Tobacco. J Med Discov. 2017; 2(1): 1-6.

[11]. Correa P, Fontham E, Pickle LW, et al. Passive smoking and lung cancer. The Lancet. 1983; 322(8350):595-597. 
[12]. Caruso RV, O'Connor RJ, Stephens WE, et al. Toxic metal concentrations in cigarettes obtained from US smokers in 2009: results from the International Tobacco Control (ITC) United States survey cohort. Int J Environ Res Public Health. 2014; 11(1):202-217.

[13]. Rayyan WA. Original Research Article The Impact of Chronic Smoking on Blood and Hair Cadmium Levels among Saudi Citizens in Hail. Sch J App Med Sci. 2016; 4(2B): 375382

[14]. Afridi HI, Talpur FN, Kazi TG, et al. Estimation of toxic elements in the samples of different cigarettes and their effect on the essential elemental status in the biological samples of Irish smoker rheumatoid arthritis consumers. Environ Monit Assess. 2015; 187(4):157.

[15]. Ciftci H \& Olcucu, A. Determination of iron, copper, cadmium and zinc in some cigarette brands in Turkey. Int J Sci Tech. 2007; 2(1): 29-32.

[16]. Jarup L. Hazards of heavy metal contamination. Br med bull. 2003; 68(1):167182.

[17]. Galazyn-Sidorczuk M, Brzoska MM \& Moniuszko-Jakoniuk J. Estimation of Polish cigarettes contamination with cadmium and lead, and exposure to these metals via smoking. Environ Monit Assess. 2008; 137(13):481-493.

[18]. Herman M \& Koscielniak, P. Analytical evaluation of the iron transfer from cigarette tobacco to human body. Nukleonika. 2004; 49(1): 39-42.

[19]. Shah BK, Nepal AK, Agrawal M, et al. The effects of cigarette smoking on hemoglobin levels compared between smokers and nonsmokers. Sunsari Tech Coll J. 2012; 1(1), 4244.

[20]. Zafar I, Mohammad KN, Nisar M, et al. Effect of cigarette smoking on erythrocytes, leukocytes and haemoglobin. J Med Sci. 2003; 3(3): 245-250.

[21]. Viroonudomphol D, Suwanton L, Pinyosirikul $\mathrm{U}$, et al. Effect of active and passive smoking on heavy metals toxic and antioxidant trace elements. J Med Biol Eng. 2016; 5(1): 58-62.

[22]. Jarup L \& Akesson A. Current status of cadmium as an environmental health problem. Toxicol Appl Pharm. 2009; 238(3): 201-208.

[23]. Anthony F. Lagalante. Atomic Absorption Spectroscopy: A tutorial review. Appl spectrosc Revs. 2004; 34(3):173-189.

[24]. Herman M \& Koscielniak, P. Analytical evaluation of the iron transfer from cigarette tobacco to human body. Nukleonika. 2004; 49, 39-42.

[25]. Lustberg M \& Silbergeld E. Blood Lead Levels and Mortality. Arch Intern Med. 2002; 162(21): 2443-2449.

[26]. Hashim A, Fatimah H, Muhammad R.C, et al. Analysis of Lead, Cadmium, and Nickel in Blood Donors in Relation to Smoking-A Comparative Study. J Environ Pathol Tox. 2019; 38(2): 165-172.

[27]. Brockhaus A, Freier I, Ewers U, et al. Levels of cadmium and lead in blood in relation to smoking, sex, occupation, and other factors in an adult population of the FRG. Int arch occup environ health. 1983; 52(2):167-175.

[28]. Ali L. Erectile dysfunction in diabetic males. Ann Pak Inst Med Sci. 2009; 5(2):117-120.

[29]. Aliomrani M, Sahraian MA, Shirkhanloo H, et al. Blood concentrations of cadmium and lead in multiple sclerosis patients from Iran. Iran J Pharm Res. 2016; 15(4):825.

[30]. Bernhard D, Rossmann A, \& Wick G. Metals in cigarette smoke. IUBMB life. 2005; 57(12): 805-809.

[31]. Nnorom I C, Osibanjo O, \& Oji-Nnorom CG. Cadmium determination in cigarettes available in Nigeria. African Journal of Biotechnology. Afr J BioTechnol. 2005; 4(10):1128-1132.

[32]. Pourkhabbaz A \& Pourkhabbaz H. Investigation of toxic metals in the tobacco of different Iranian cigarette brands and related health issues. Iran J Basic Med Sci. 2012; 15(1): 636.

[33]. Ashraf MW. Levels of heavy metals in popular cigarette brands and exposure to these metals via smoking. The Sci World J. 2012; 2012(1):5.

[34]. Cloonan SM, Mumby S, Adcock IM, et al. The "iron"-y of iron overload and iron deficiency in chronic obstructive pulmonary disease. Am J Resp Crit Care med. 2017; 196(9): 1103-1112.

[35]. Milman N \& Pedersen, A. N. Blood haemoglobin concentrations are higher in smokers and heavy alcohol consumers than in non-smokers and abstainers-should we adjust the reference range. Ann Hematol. 2009; 88(7), 687. 